\title{
Environmental Estimation of Radiation Equivalent Dose Rates in Soils and Waters of Northern Calabria (Italy)
}

\author{
Ilaria Guagliardi $\mathbb{D}^{1},{ }^{1}$ Tommaso Caloiero $\mathbb{D}^{1},{ }^{1}$ Ernesto Infusino $\mathbb{D}^{1,2}$ Giovanni Callegari, ${ }^{1}$ \\ and Nicola Ricca iD ${ }^{1}$ \\ ${ }^{1}$ National Research Council of Italy, Institute for Agricultural and Forest Systems in the Mediterranean (CNR-ISAFOM), \\ 87036 Rende, Italy \\ ${ }^{2}$ University of Calabria, Department of Environmental Engineering (DIAm), Rende, Italy
}

Correspondence should be addressed to Tommaso Caloiero; tommaso.caloiero@isafom.cnr.it

Received 23 October 2020; Revised 7 December 2020; Accepted 15 April 2021; Published 27 April 2021

Academic Editor: Jinze Xu

Copyright (c) 2021 Ilaria Guagliardi et al. This is an open access article distributed under the Creative Commons Attribution License, which permits unrestricted use, distribution, and reproduction in any medium, provided the original work is properly cited.

\begin{abstract}
In this study, the equivalent dose rate of natural radionuclides $\left(H_{T}\right)$ in 99 spring water and surface soil samples was determined using an alpha, beta, and gamma high sensitivity detector up within a Geiger-Muller tube and with an external probe $\mathrm{NaI}$ (Tl). The samples were collected in the Crati basin (southern Italy), and during sample collection, water quality parameters were detected in situ and at the University of Calabria laboratories. A Pearson correlation coefficient analysis was applied to identify and clarify the relationships between water physical-chemical properties and soil and water radioactivity. Results show that the mean $H_{T}$ for spring waters is $97.07 \mu \mathrm{Sv} / \mathrm{h}$. Furthermore, the mean $H_{T}$ for surface soils is $97.92 \mu \mathrm{Sv} / \mathrm{h}$, thus evidencing higher mean $H_{T}$ values than worldwide ones reported in a previous literature. Low correlation coefficients were detected between water $H_{T}$ and conductivity and $\mathrm{pH}$. On the contrary, a reasonable correlation was found between $H_{T}$ in spring water and in soil. This relationship is associated with some rocks of the Sila Massif and of Coastal Chain, i.e., plutonic and metamorphic crystalline rocks. Finally, the estimation of the health risk was calculated: results did not evidence serious dangers for people living in the studied environment. The results from this survey for the $H_{T}$ evaluation provide an extensive assessment of the background exposure levels in the investigated area.
\end{abstract}

\section{Introduction}

Knowledge of environmental natural radioactivity is essential to assess the current level of radiation exposure of the population and the degree of radioactive pollution in the environment in the future [1]. In fact, environmental radioactivity is the major source of radioactivity absorbed by people worldwide $[2,3]$ and cannot be avoided. Moreover, considering geochemical studies, it represents a significant source of information. Indeed, radiometric data can be used to coherently interpret correlations between radioelement distribution and other elements and to support the interpretation of petrogenetic or pedogenetic associations [4-6]. The evaluation of the environment natural radioactivity is also paramount to progressively monitor possible changes in natural background activity, as a result of radioactivity release [6].
Due to natural and man-made sources, a different level of radioactivity can be identified in the earth's crust $[7,8]$. Naturally occurring radioactive materials include radioactive decay "chains" beginning with ${ }^{238} \mathrm{U},{ }^{235} \mathrm{U}$ and ${ }^{232} \mathrm{Th}$, along with ${ }^{40} \mathrm{~K},{ }^{37} \mathrm{Rb}$, and other radioactive isotopes [9]. In particular, ${ }^{238} \mathrm{U}$ constitutes $99.3 \%$ of the isotopes of uranium found in nature, and thus, ${ }^{235} \mathrm{U}(0.7 \%)$, which provides a relatively insignificant radiation dose, is not surveyed further [10].

The distribution of naturally occurring radionuclides (principally ${ }^{238} \mathrm{U},{ }^{232} \mathrm{Th}$, and their daughter products) and ${ }^{40} \mathrm{~K}$ (among other radioactive elements) is strictly related to the distribution of rocks originating them and depends on the processes connected with their concentration [11]: it is caused by the decay of radionuclides derived from minerals. Consequently, the radioactivity amount in the soil depends on geology, soil type, soil moisture, organic matter, soil $\mathrm{pH}$, 


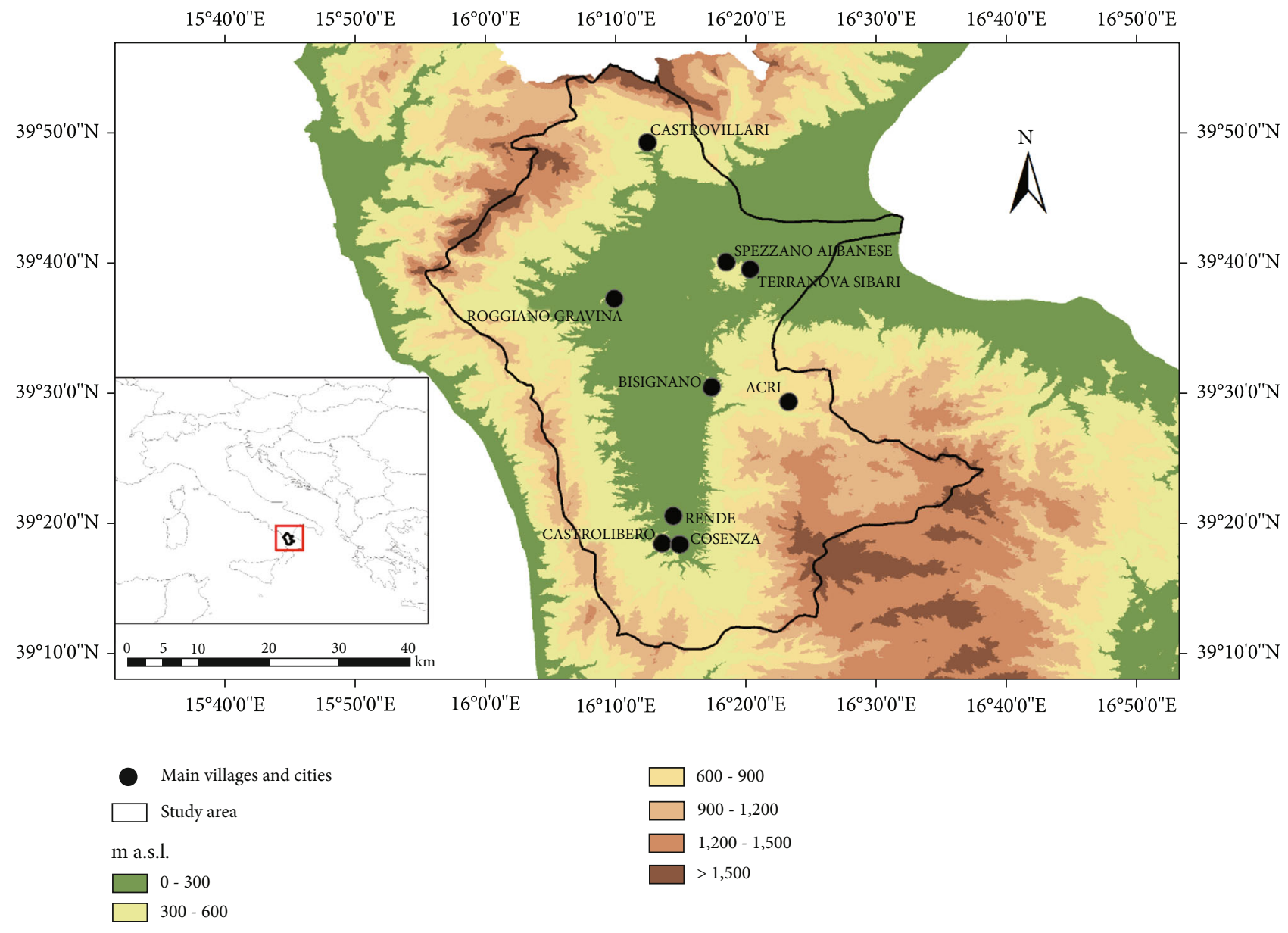

FIgURE 1: Crati river basin.

and climate with regard to the pluviometric and the thermometric regime of a region $[12,13]$. Therefore, the concentrations of radionuclides vary widely depending on the location. Geologically, given the increasing uranium content of a rock with the silica content, high radiation levels can be generally found in igneous rocks, such as granite. In fact, some minerals which can be enriched in uranium and thorium (e.g., ilmenite, zircon, garnet, magnetite, rutile, and monazite) constitute the common mineral suites of these rocks. On the other hand, in some rock-forming, such as orthoclase, and accessory heavy minerals, the presence of potassium largely occurs. Lower levels are related to sedimentary rocks but with some peculiarity. In fact, in some shale and phosphate rocks a rather high content of radionuclides can be detected [14].

Environmentally, the soil on the earth's crust can be considered a radioactive threat because it is a source of continuous exposure for the population and because, considering agricultural soil, it allows radionuclides to enter the food chain and thus to contaminate humans through crops $[15,16]$. Indeed, the soil-to-plant transfer can be considered a paramount process since; in the long run, radioelements enter the human food chains through the uptake of plant roots.

In addition, natural radioactive decay series can be dissolved in water and then move to surface water reservoirs, thus contributing to public radiation exposure [17]. This occurs especially, when aquatic organisms and plants keep radioisotopes coming from river soil and sediment [3].

Globally, an average radioactive dose from natural sources equal to about $2.4 \mathrm{mSv} / \mathrm{y}$ has been estimated. The exposure can be external, deriving from direct radiation, both cosmic and terrestrial, or internal, originating from the possible inhalation or ingestion of terrestrial and cosmogenic radionuclides which can be found in air, water, food, and soil. In particular, considering the world population, results of the assessments of the whole radiation dose evidenced that this is due to natural and artificial sources in fractions of about $96 \%$ and $4 \%$, respectively [18].

The absorbed dose rates can be evaluated directly, thus allowing an even more extensive estimation of the background exposure levels in the study areas. Results of the spectrometric measurements show that, in both outdoors and indoors, the three items of the external radiation field, ${ }^{238} \mathrm{U}$, ${ }^{232} \mathrm{Th}$, and ${ }^{40} \mathrm{~K}$ contributed equally to the externally incident gamma radiation dose to individual [19].

The dose received by each single members of the population can significantly vary considering the different sources. In fact, while all the population can be affected by some sources of radiation, in other cases, only few individuals can be exposed. For example, considering natural radioactivity, this can be found in all the soils, thus exposing all the 


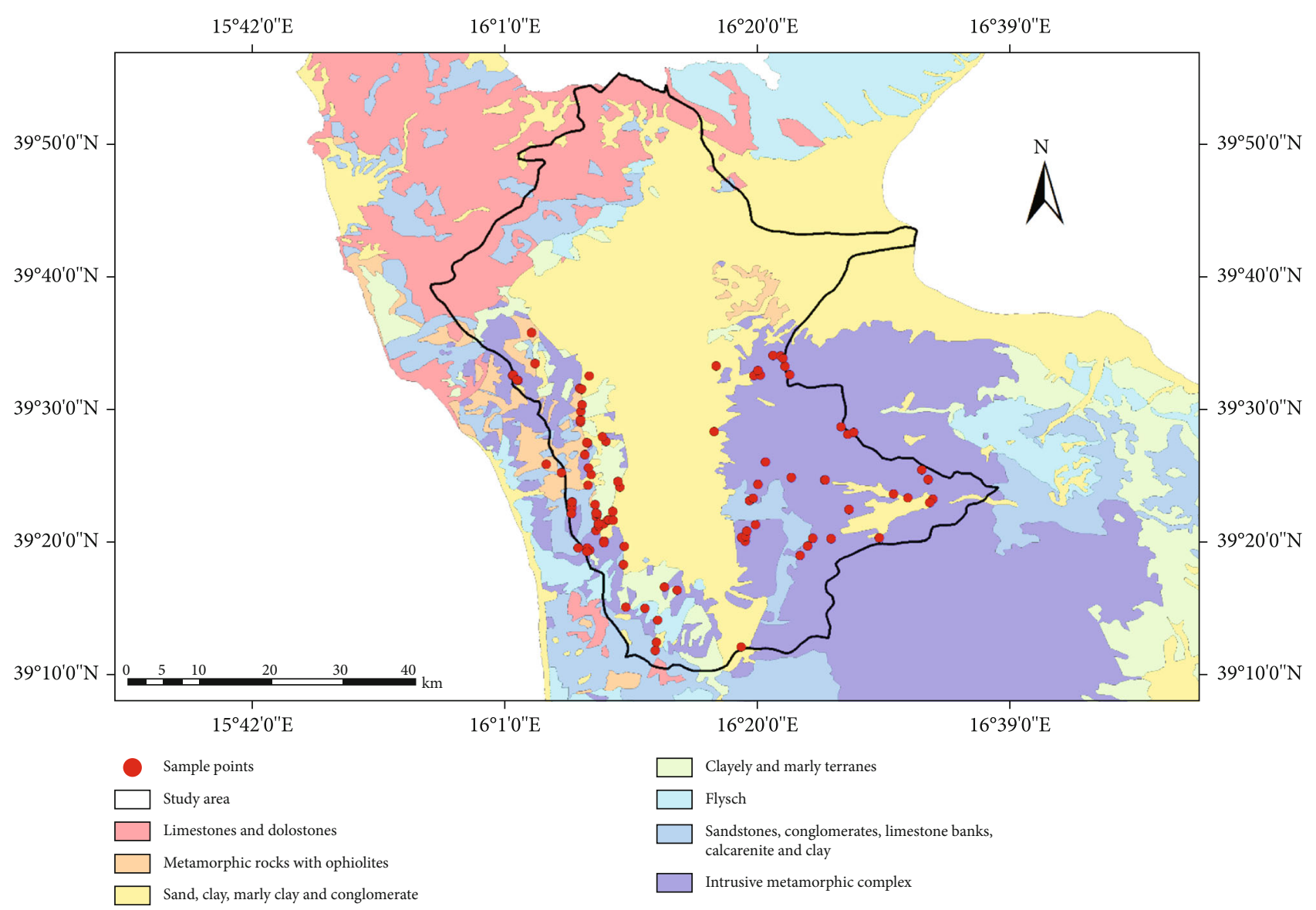

FIGURE 2: Lithological map of the study area and sample points.

population to some radiation dose. Conversely, considering the case of medical exposures, only people directly involved in medical treatment with radiation can receive a radiation dose [10].

Since the present study represents the first examination of a more detailed environmental survey, it offers an interesting and informative source to delineate the natural radiation equivalent dose rates in soils and waters of the Calabria region, located in southern Italy. Its preliminary findings illustrate a global overview of the study area setting and show that there are many future investigations needed. In particular, exploring and mapping the activity of the naturally occurring radionuclides are necessary and required in order to have information about the environment radiation level to assess the interaction between ionizing radiation and the human body. Thus, the survey performed in this study is aimed at quantifying the dose of radiation exposure, obtained from environmental radiation, in order to detect the possible risks for the public health caused by radiations from natural sources. Moreover, data obtained in this survey can contribute to the global data bank on radioactivity, thus allowing a more detailed evaluation of the mean values of the dosimetric quantities at global scale. The contribution to this data bank is especially important since these data allow a better understanding of the effects of low-level radiation in human health.

\section{Site Characterization}

The Crati basin is the largest and most important basin in the Calabria region [20]. It has an area of $2447.7 \mathrm{~km}^{2}$ and a perimeter of about $320 \mathrm{~km}$, with an elevation ranging from sea level to $2258 \mathrm{~m}$ a.s.l. and an average altitude of $597 \mathrm{~m}$ a.s.l. (Figure 1). Due to its dimension, the hydrographical system flowing in the basin includes waters deriving from several geological formations. The climate of the basin is largely influenced by its orography and its position in the middle of the Mediterranean basin [21-23]. Indeed, a hot summer Mediterranean climate, with very warm dry summers and mild rainy winters, characterizes the basin following the Köppen-Geiger classification [24].

The Crati basin is a depressed block of the crust bordered by parallel faults and circumscribed by the Sila Massif to the east, the Coastal Chain to the west and south, and the Pollino group to the north which represent the three morphostructural highs of the northern Calabria. The first one is composed by plutonic and metamorphic crystalline rocks, the second one by crystalline and sedimentary rocks, and the last one by carbonate and siliciclastic sedimentary rocks.

Geologically, it is branded by a succession of pliocenic sediments overlaying on Paleozoic intrusive-metamorphic complex (Figure 2). The lithological composition of this last one is characterized by paragneiss, biotite schists, and gray 
phyllitic schists with quartz, chlorite, and muscovite, frequently affected by a weathering process [25].

The Coastal Chain shows, along its margins, the Miocene deposits characterized by the presence of basal conglomerate passing to sand, sandstone, calcarenite, and clay; the Messinian evaporite deposits is composed of conglomerate, marl, limestone, and clay with intercalated gypsum. Basal microconglomerate and sandstone evolving to clay characterize the Early Pliocene deposits. Polygenic conglomerate passing to marly clay, sand, and sandstone followed by marly clay, regressive sand, and conglomerate distinguishes the Upper Pliocene-Pleistocene sequences. Over these last ones, terraced marine deposits of Middle Pleistocene occur. Lastly, Holocene alluvial deposits crop out along the main river plains [26].

As evidenced in the regional soil map at $1: 250,000$ scale [27] the leading soil types of the study area vary from poorly to moderately differentiated soils, such as Fluvisols, Leptosols, Arenosols, Cambisols, Calcisols, Umbrisols, and Phaeozems to more developed Vertisols and Luvisols [28] and Entisols, Inceptisols, Mollisols, Vertisols, and Alfisols [29]. Intermediate soil properties between the ones typical of cold and subtropical climates characterize the Calabria region [30]. These features yield a manifest seasonality in radionuclides given the marked contrasts in temperature and relative humidity [31].

Concerning the spring waters in the study area and according to Gaglioti et al. [32], they are bicarbonate alkaline-earth and chloride-sulphate alkaline-earth waters. These findings reflect the global lithological environment of the study area. In fact, in the Coastal Chain, it mainly constituted calcareous and carbonatic rocks (providing high $\mathrm{Ca}^{2+}$, $\mathrm{Mg}^{2+}$, and $\mathrm{HCO}^{3-}$ ion concentration in water), while in the Sila Massif it is constituted by intrusive magmatic or metamorphic rocks (providing high $\mathrm{SO}_{4}{ }^{2-}$ and $\mathrm{Cl}^{-}$ion concentration in water).

\section{Methodology}

3.1. Sample Collection and Measurement Set-Up. In this study, 99 spring water and surface soil samples were analysed. Given the dimension of the basin (about $2400 \mathrm{~km}^{2}$ ), the number of sampled points reflects the several outcropping geological formations in the study area.

In these sample locations, the equivalent dose rate of natural radionuclides $\left(H_{T}\right)$ was determined at $1 \mathrm{~m}$ above the ground using an $\alpha, \beta$, and $\gamma$ high sensitivity detector up within a Geiger-Muller tube and with an external probe $\mathrm{NaI}(\mathrm{Tl})$.

During the sample collection, water quality parameters (temperature, $\mathrm{pH}$, and conductivity) were detected in situ and at the University of Calabria laboratories. Air temperature was also measured. The technical specifications of the measurement apparatus are indicated in Table 1.

3.2. Equivalent Dose and Health Risk. The radiation dose, when reaching body tissues and organs, chains itself with the part of the body affected, the exposure pathway; therefore, no adsorbed Becquerel of radioactivity vehicles the same
TABLE 1: Technical specifications of the radiation detector.

\begin{tabular}{|c|c|}
\hline Inside Geiger-Muller detector & \\
\hline Energy range & $0.06-3 \mathrm{MeV}$ \\
\hline $\begin{array}{l}\text { Accrual of environmental } \\
\text { equivalent dose }\end{array}$ & $10 \mu \mathrm{Sv} / \mathrm{h}-100 \mathrm{mSv} / \mathrm{h}$ \\
\hline Environmental equivalent dose & $10 \mu \mathrm{Sv}-1 \mathrm{~Sv}$ \\
\hline Sensitivity with ${ }^{137}$ Cs source & $0.3 \mathrm{cps} / \mu \mathrm{Sv} \cdot \mathrm{h}-1$ \\
\hline Weight & $0.5 \mathrm{~kg}$ \\
\hline Dimensions & $92 \times 62 \times 52 \mathrm{~mm}$ \\
\hline \multicolumn{2}{|c|}{ Detector NaI (TI) diam. $40 \times 40 \mathrm{~mm}$. External probe } \\
\hline Energy range & $0.04-3 \mathrm{MeV}$ \\
\hline $\begin{array}{l}\text { Accrual of environmental } \\
\text { equivalent dose }\end{array}$ & 0.03 to $100 \mu \mathrm{Sv} / \mathrm{h}$ \\
\hline Environmental equivalent dose & $0.03 \mu \mathrm{Sv}-0.3 \mathrm{~Sv}$ \\
\hline Sensitivity with ${ }^{137} \mathrm{Cs}$ source & $900 \mathrm{cps} / \mu \mathrm{Sv} \cdot \mathrm{h}-1$ \\
\hline Weight & $1.2 \mathrm{~kg}$ \\
\hline Dimensions & diam. $60 \times 320 \mathrm{~mm}$ \\
\hline \multicolumn{2}{|l|}{ General characteristics } \\
\hline Intrinsic measurement error & $\pm 20 \%$ \\
\hline Protection class & IP64 \\
\hline Autonomy & $24 \mathrm{~h}$ \\
\hline Operating temperature & $-30^{\circ}$ to $+50^{\circ}$ \\
\hline $\begin{array}{l}\text { Relative moisture at } 35^{\circ} \text { and below } \\
\text { the compensation limit }\end{array}$ & Up to $95 \%$ \\
\hline \multirow[t]{2}{*}{ Beam } & Extensible \\
\hline & Internal batteries MI-MH $6 \mathrm{~V}$ \\
\hline \multirow[t]{2}{*}{ Power source } & AC, $50 \mathrm{~Hz} 220 \mathrm{~V}$ \\
\hline & DC $12 \mathrm{~V}$ \\
\hline Radio interference & CEI/IEC CISPR $22: 1997$ \\
\hline Electromagnetic compatibility & $\begin{array}{l}\text { CEI/IEC 61000-4-2: } 1995- \\
\text { IEC 61000-4-3: } 1995\end{array}$ \\
\hline
\end{tabular}

equal radiation dose as another. In order to assess the differences of the various radiations, which have dissimilar biological impacts, the unit "equivalent dose" (symbol $H_{T}$ ), whose measuring unit is the Sieverts (Sv), has been conventionally adopted. Quantitatively, the equivalent dose has a higher biological significance than the absorbed dose.

To calculate the $H_{T}$, a multiplication of the absorbed dose to the organ or tissue (DT) with the radiation weighting factor, $w R$, is required. $w R$ is strictly associated to the type and energy of the incident radiation. Its value is 1 for $\mathrm{X}$-rays, gamma rays, and beta particles and higher for protons $(w R=5)$, neutrons ( $w R$ is between 5 and 20 depending on energy), alpha particles, and heavy fragments $(w R=20)$ [33].

The estimation of fatal cancer risk for an individual, $\widehat{R}_{i}$, is defined by equation (1) [34]:

$$
\widehat{R}_{i}=a H_{T}
$$

where $a$ is the risk factor equal to 0.05 Sievert for terrestrial gamma radiation dose [35] and $H_{T}$ is the equivalent dose rate. 
TABLE 2: Main descriptive statistics of the measured parameters.

\begin{tabular}{|c|c|c|c|c|c|c|}
\hline Statistics & Air $T\left({ }^{\circ} \mathrm{C}\right)$ & Water $T\left({ }^{\circ} \mathrm{C}\right)$ & $\mathrm{pH}$ & Conductivity $(\mathrm{S} / \mathrm{cm})$ & Water $H_{T}(\mu \mathrm{Sv} / \mathrm{h})$ & Soil $H_{T}(\mu \mathrm{Sv} / \mathrm{h})$ \\
\hline Minimum & 14.00 & 9.90 & 6.09 & 23.10 & 31.00 & 31.00 \\
\hline Maximum & 32.00 & 32.00 & 8.59 & 1984.00 & 175.00 & 147.00 \\
\hline Mean & 23.94 & 16.70 & 7.01 & 227.42 & 97.07 & 97.92 \\
\hline Median & 24.00 & 16.20 & 6.96 & 170.30 & 95.00 & 95.00 \\
\hline St. Dev. & 4.75 & 4.00 & 0.54 & 242.47 & 27.19 & 25.31 \\
\hline Skewness & -0.01 & 1.41 & 0.68 & 4.54 & 0.25 & -0.01 \\
\hline Kurtosis & -0.87 & 3.01 & 0.02 & 28.41 & 0.17 & -0.74 \\
\hline
\end{tabular}

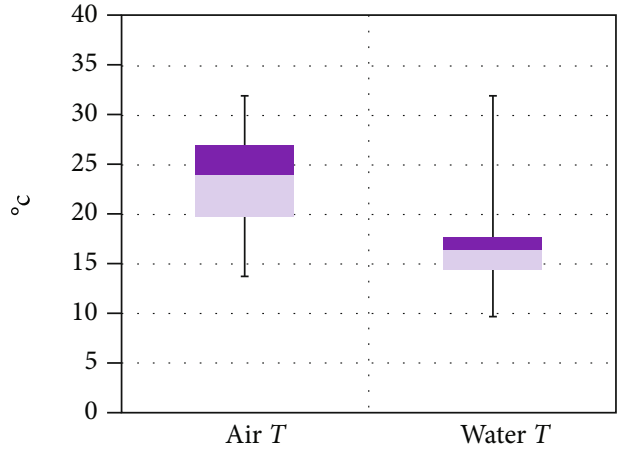

(a)

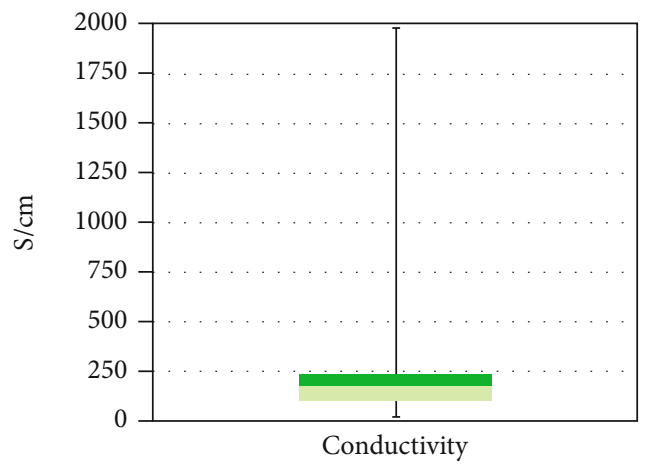

(c)

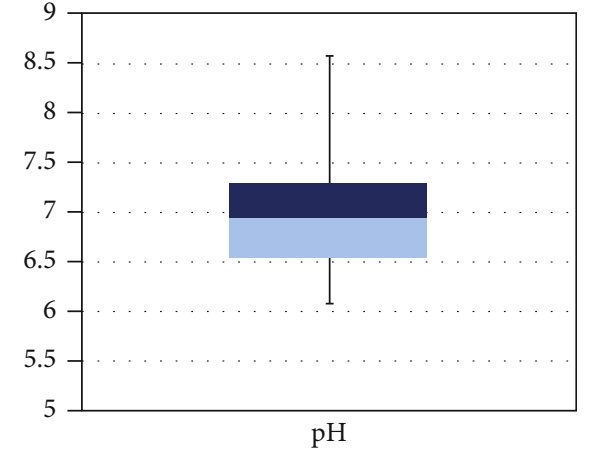

(b)

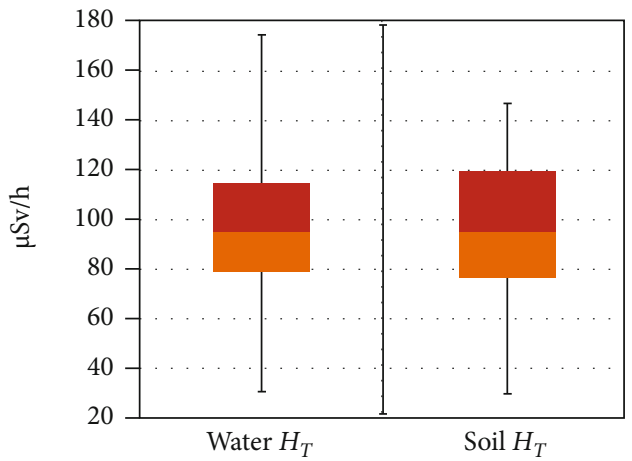

(d)

FIgURE 3: Boxplots of measured parameters.

\section{Results and Discussion}

Results show that the mean $H_{T}$ for spring waters is $97.07 \mu \mathrm{Sv} / \mathrm{h}$, with a maximum value of $175 \mu \mathrm{Sv} / \mathrm{h}$ and a minimum of $31 \mu \mathrm{Sv} / \mathrm{h}$ (Table 2). Furthermore, the mean $H_{T}$ for surface soils is $97.92 \mu \mathrm{Sv} / \mathrm{h}$, with a maximum value of $147 \mu \mathrm{Sv} / \mathrm{h}$ and a minimum of $31 \mu \mathrm{Sv} / \mathrm{h}$ (Table 2).

The main descriptive statistics of measured parameters are shown in Figure 3.

The Pearson correlation coefficient analysis was applied to identify the relationships between water physical-chemical properties, soil, and water radioactivity.

Low correlation coefficients were detected between the water $H_{T}$ and conductivity and $\mathrm{pH}$, with $R^{2}$ values equal to 0.057 and 0.1 , respectively. On the contrary, a reasonable correlation was found between $H_{T}$ in water and soil. This relationship is associated with some rocks (plutonic and metamorphic crystalline) of the Sila Massif and of the Coastal Chain, upon which the Crati basin soils are imposed.

According to Guagliardi et al. [13], a strong control on radioactivity can be assessed by considering the foremost pedogenetic features showed in the soil map of the Calabria region [27]. The soil sampling locations involved several soil types and geological background. The highest $H_{T}$ values have been detected in locations characterized by soil type that originates mainly from igneous-metamorphic rocks (Figure 4) or in fairly young soils such as Fluvisols, Leptosols, and Cambisols. On the contrary, in older soils constituted on conglomerates and sands (Luvisols and Arenosols), lower values were mainly recorded.

In the Sila Massif, primary minerals constituting rocks contain K, U, and Th. Monazite, zircon, and K-feldspar are 


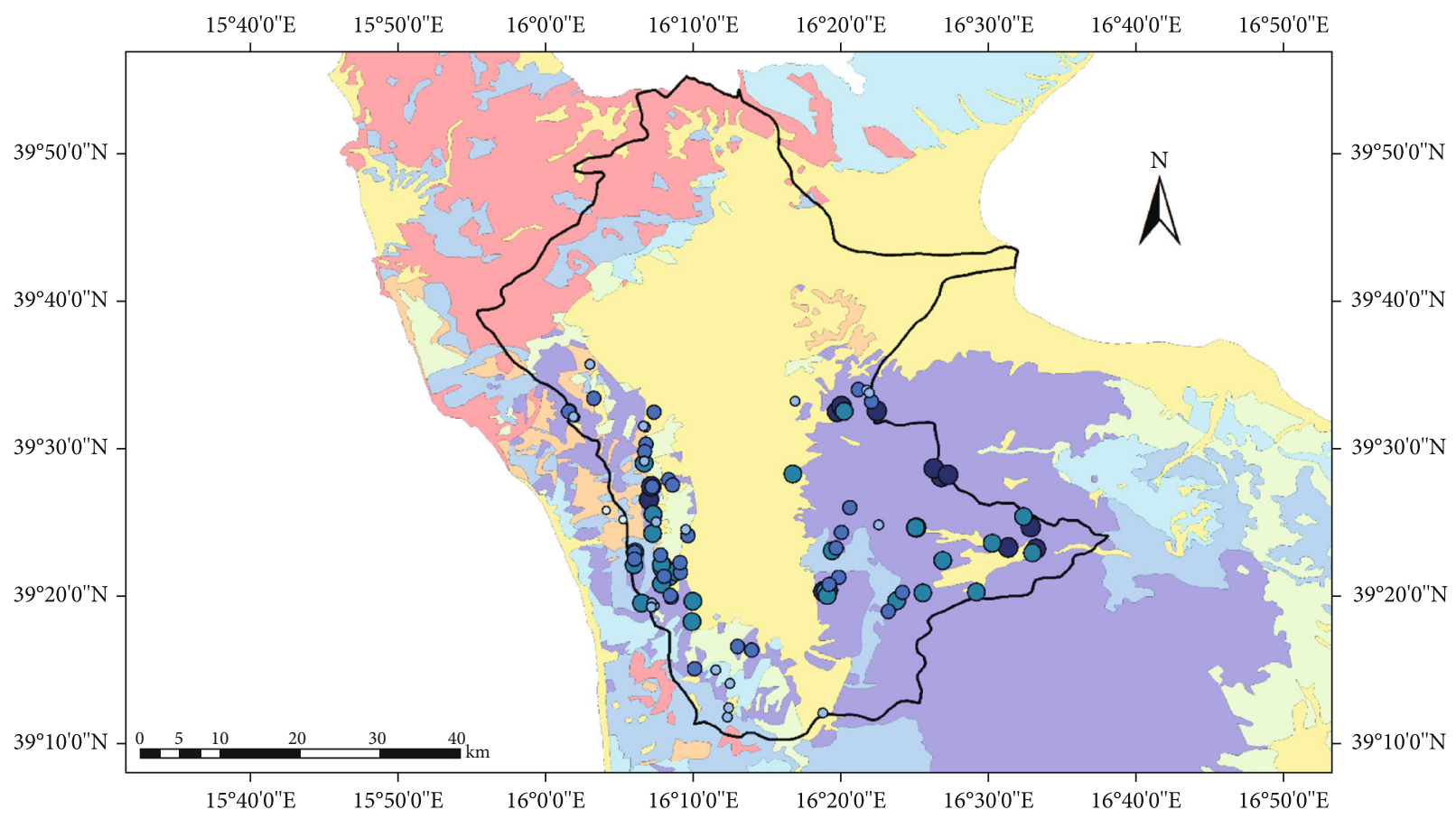
Soil $\mathrm{H}_{\mathrm{T}}(\mu \mathrm{Sv} / \mathrm{h})$
$\circ<50$
$100-125$
○ $50-75$
$>125$
$75-100$
Study area

FIGURE 4: Dot map of equivalent dose rate in soils.

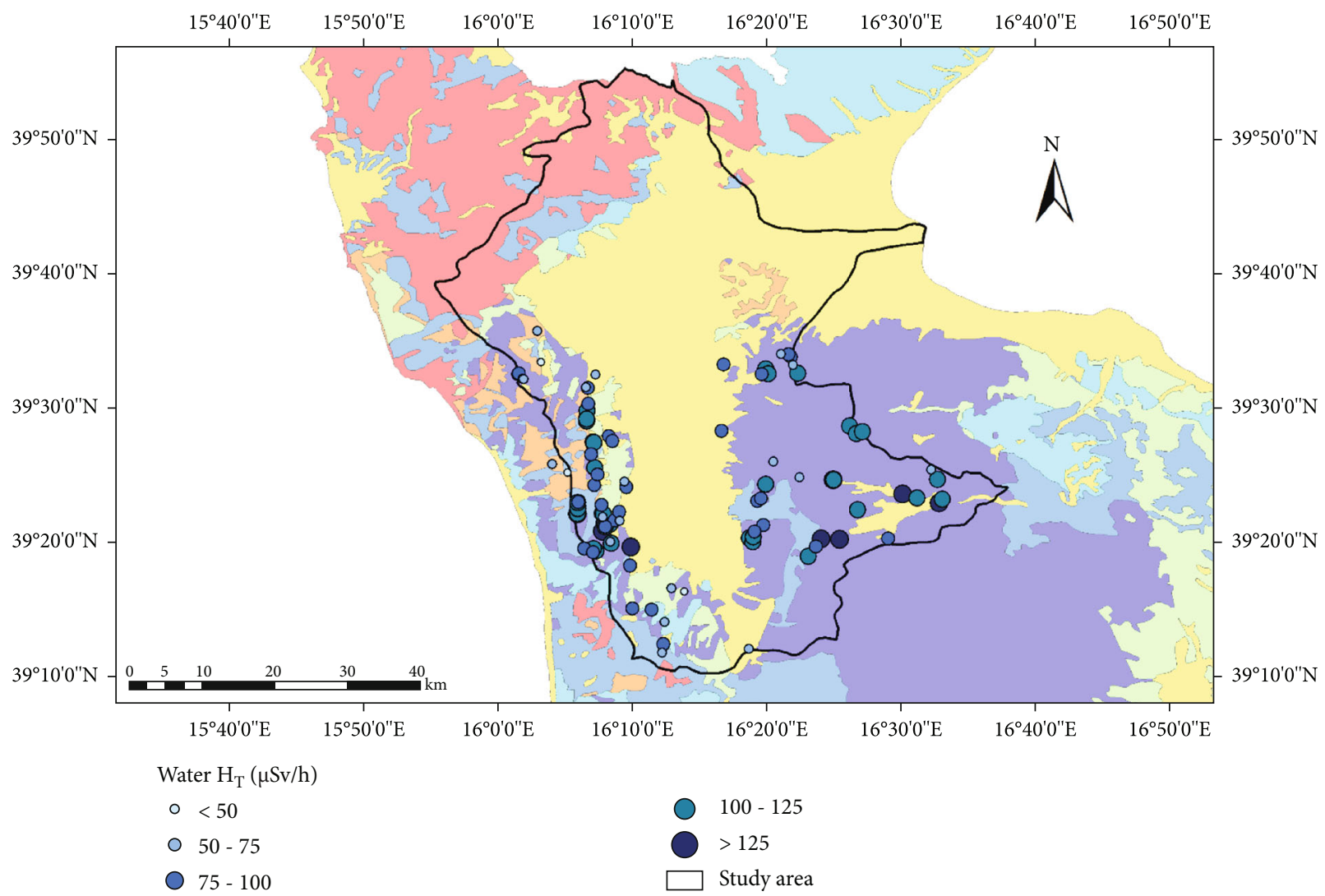

Figure 5: Dot map of equivalent dose rate in waters. 
responsible of the apparent activity of the radionuclides. Specifically, in monazite, primarily radionuclides from the ${ }^{232} \mathrm{Th}$ series and from the ${ }^{238} \mathrm{U}$ series occur. Plagioclase and total feldspar content are related to U activities. Likewise, the primary minerals (such as K-feldspars, muscovite, and biotite) and the neo-formed phyllosilicate clays such as illite, which is a common weathering product of primary micas [36], contains potassium.

Similar outcomes can be assessed for the equivalent dose rates in waters (Figure 5). According to Gaglioti et al. [32], the sampled waters have origin in the calcareous and carbonatic rocks of the Coastal Chain and intrusive magmatic or metamorphic rocks of the Sila Massif, and consequently, their equivalent dose rates well fit the elemental distribution of the undergoing lithologies.

In order to assess the health effects, the soil radiation dose rate in the studied locations was calculated considering the UNSCEAR [19] recommendation using a factor of 0.007 to obtain units of radiation dose (in $\mu \mathrm{Sv} / \mathrm{h}$ ) from an absorbed dose rate in air (in $\mu \mathrm{Gy} / \mathrm{h}$ ). The soil radiation dose rate in the study area ranged from $4429 \mu \mathrm{Gy} / \mathrm{h}$ to $21000 \mu \mathrm{Gy} / \mathrm{h}$ with the mean value of $13989 \mu \mathrm{Gy} / \mathrm{h}$. The range of this value falls within the average world value of $5700 \mu \mathrm{Gy} / \mathrm{h}$ [19], but the mean one is 2 times higher than it.

The mean effective dose in the soil area is $97.92 \mu \mathrm{Sv} / \mathrm{h}$. Using equation (1), this value will cause fatal cancer risk of about $43 \times 10^{6}$ per year to each individual in the area.

Nowadays, as a result of several studies performed worldwide, it has been generally recognized that, for radiation exposure doses lower than $100 \mathrm{mSv}$, statistically significant cancer excess has not been detected [37-43]. The health hazard evaluation shows that no significant radiological impact of the population occurs in the study area. This does not exempt the scientific community from paying attention to these issues because even if there is a dosage of low-level radiation below which no damage occurs, a long-term exposure can cause health damage.

\section{Conclusions}

Ionizing radiation from natural and anthropogenic sources concurs to human exposure and therefore constitutes a potential risk to human health.

The results from this survey for the $H_{T}$ assessment provide a preliminary evaluation of the background exposure levels in the Crati basin in the Calabria region. For both soil and water, the highest $H_{T}$ values were found at locations with soil types that originate mainly from igneousmetamorphic rocks and/or in relatively young soils. Conversely, the lowest values occur in older soils imposed on conglomerates and sands.

These equivalent dose rates do not pose a serious radioactive health hazard to the population living in the environment. However, exposure to the dose level over a long period can constitute a serious health risk. The results can reliably serve as reference values for the assessment of the equivalent dose due to natural radioactivity in the environment.

\section{Data Availability}

The data that support the findings of this study are available from the corresponding author upon reasonable request.

\section{Conflicts of Interest}

The authors declare that they have no conflicts of interest.

\section{References}

[1] M. M. Saç, F. Ortabuk, M. N. Kumru, M. İçhedef, and Ş. Sert, "Determination of radioactivity and heavy metals of Bakirçay river in Western Turkey," Applied Radiation and Isotopes, vol. 70, no. 10, pp. 2494-2499, 2012.

[2] A. K. Amanjeet, S. Kumar, J. Singh, P. Singh, and B. S. Bajwa, "Assessment of natural radioactivity levels and associated dose rates in soil samples from historical city Panipat, India," Journal of Radiation Research and Applied Sciences, vol. 10, no. 3, pp. 283-288, 2017.

[3] M. A. Saleh, A. T. Ramli, Y. Alajerami, and A. S. Aliyu, "Assessment of natural radiation levels and associated dose rates from surface soils in Pontian district, Johor, Malaysia," Journal of Ovonic Research, vol. 9, pp. 17-27, 2013.

[4] I. Guagliardi, G. Buttafuoco, and C. Apollaro, "Using gammaray spectrometry and geostatistics for assessing geochemical behaviour of radioactive elements in the lese catchment (southern Italy)," International Journal of Environmental Research, vol. 7, pp. 645-658, 2013.

[5] IAEA, Guidelines for Radioelement Mapping Using Gamma Ray Spectrometry Data, IAEA-TECDOC-1363, International Atomic Energy Agency, Vienna, 2003.

[6] M. M. Mehade Hasan, M. I. Ali, D. Paul, M. A. Haydar, and S. M. A. Islam, "Natural radioactivity and assessment of associated radiation hazards in soil and water samples collected from in and around of the Barapukuria $2 \times 125 \mathrm{MW}$ coal fired thermal power plant, Dinajpur, Bangladesh," Journal of Nuclear and Particle Physics, vol. 4, pp. 17-24, 2014.

[7] N. Akhtar, M. Tufail, M. Ashraf, and M. M. Iqbal, "Measurement of environmental radioactivity for estimation of radiation exposure from saline soil of Lahore, Pakistan," Radiation Measurements, vol. 39, no. 1, pp. 11-14, 2005.

[8] A. Faanu, O. K. Adukpo, L. Tettey-Larbi et al., "Natural radioactivity levels in soils, rocks and water at a mining concession of Perseus gold mine and surrounding towns in Central Region of Ghana," SpringerPlus, vol. 5, no. 1, 2016.

[9] T. M. Missimer, C. Teaf, R. G. Maliva, A. Danley-Thomson, D. Covert, and M. Hegy, "Natural radiation in the rocks, soils, and groundwater of Southern Florida with a discussion on potential health impacts," International Journal of Environmental Research and Public Health, vol. 16, no. 10, p. 1793, 2019.

[10] P. A. Colgan, C. Organo, C. Hone, and D. Fenton, Radiation Doses Received by the Irish Population, Radiological Protection Institute of Ireland, Dublin, 2008.

[11] I. Guagliardi, D. Zuzolo, S. Albanese et al., "Uranium, thorium and potassium insights on Campania region (Italy) soils: sources patterns based on compositional data analysis and fractal model," Journal of Geochemical Exploration, vol. 212, p. 106508, 2020.

[12] I. Guagliardi, N. Rovella, C. Apollaro et al., "Modelling seasonal variations of natural radioactivity in soils: a case study 
in southern Italy," Journal of Earth System Science, vol. 125, no. 8, pp. 1569-1578, 2016.

[13] I. Guagliardi, N. Rovella, C. Apollaro et al., "Effects of source rocks, soil features and climate on natural gamma radioactivity in the Crati valley (Calabria, Southern Italy)," Chemosphere, vol. 150, pp. 97-108, 2016.

[14] I. El-Taher and J. H. Al-Zahrani, "Radiaoctivity measurements and radiation dose assessments in soil of Al-Qassim region, Saudi Arabia," Indian Journal of Pure \& Applied Physics, vol. 52, pp. 147-154, 2014.

[15] I. Guagliardi, G. Buttafuoco, and N. Ricca, "Modelling seasonal variations of natural radionuclides in agricultural soils," in In Proceedings of the $3 S$ Web of Conferences, vol. 1, 2013b.

[16] H. D. Van, T. D. Nguyen, A. Peka, M. Hegedus, A. Csordas, and T. Kovacs, "Study of soil to plant transfer factors of 226Ra, 232Th, 40K and 137Cs in Vietnamese crops," Journal of Environmental Radioactivity, vol. 223-224, 2020.

[17] S. J. Al-Kharouf, I. F. Al-Hamarneh, and M. Dababneh, "Natural radioactivity, dose assessment and uranium uptake by agricultural crops at Khan Al-Zabeeb, Jordan," Journal of Environmental Radioactivity, vol. 99, no. 7, pp. 1192-1199, 2008.

[18] M. P. Chougankar, K. P. Eppen, and T. V. Ramachandran, "Profiles of doses to population living in the high background radiation areas in Kerala," Journal of Environmental Radioactivity, vol. 71, pp. 275-297, 2004.

[19] UNSCEAR, Sources and Effects of Ionizing Radiation, Report of the United Nations Scientific Committee on the Effects of Atomic Radiation to the General Assembly, United Nations, New York, 2000.

[20] R. Coscarelli, R. Gaudio, and T. Caloiero, "Climatic trends: an investigation for a Calabrian basin (southern Italy)," in In Proceedings of the International Symposium The basis of civilization. Water science?, vol. 286, pp. 255-266, IAHS, Wallingford, IAHS Publications, 2004.

[21] G. Buttafuoco, T. Caloiero, N. Ricca, and I. Guagliardi, "Assessment of drought and its uncertainty in a southern Italy area (Calabria region)," Measurement, vol. 113, pp. 205-210, 2018.

[22] G. Pellicone, T. Caloiero, and I. Guagliardi, "The De Martonne aridity index in Calabria (Southern Italy)," Journal of Maps, vol. 15, no. 2, pp. 788-796, 2019.

[23] G. Pellicone, T. Caloiero, G. Modica, and I. Guagliardi, “Application of several spatial interpolation techniques to monthly rainfall data in the Calabria region (southern Italy)," International Journal of Climatology, vol. 38, no. 9, pp. 3651-3666, 2018.

[24] H. E. Beck, N. E. Zimmermann, T. R. McVicar, N. Vergopolan, A. Berg, and E. F. Wood, "Present and future Koppen-Geiger climate classification maps at $1-\mathrm{km}$ resolution," Scientific Data, vol. 5, no. 1, 2018.

[25] I. Guagliardi, N. Ricca, and D. Cicchella, "From rock to soil: geochemical pathway of elements in Cosenza and Rende area (Calabria, southern Italy)," Rendiconti Online della Società Geologica Italiana, vol. 38, pp. 55-58, 2016.

[26] G. Iovine, I. Guagliardi, C. Bruno et al., "Soil-gas radon anomalies in three study areas of Central-Northern Calabria (Southern Italy)," Natural Hazards, vol. 91, pp. 193-219, 2018.

[27] ARSSA, I suoli della Calabria. Carta dei suoli in scala 1:250000 della Regione Calabria. Monografia divulgativa: Programma Interregionale Agricoltura-Qualità, Rubbettino Ed., Catanzaro, 2003.
[28] IUSS Working Group WRB, International Soil Classification System for Naming Soils and Creating Legends for Soil Maps, no. 106, 2014World Soil Resources Reports, FAO, Rome, 2014.

[29] Soil Survey Staff, Keys to Soil Taxonomy, United States Department of Agriculture (USDA), Natural Resources Conservation Service (NRCS), Washington DC, 2014.

[30] M. Llaurado, M. Vidal, G. Rauret, C. Roca, J. Fons, and V. R. Vallejo, "Radiocaesium behaviour in Mediterranean conditions," Journal of Environmental Radioactivity, vol. 23, no. 1, pp. 81-100, 1994.

[31] A. Baeza, J. Paniagua, M. Rufo, J. Guilléna, and A. Sterling, "Seasonal variations in radionuclide transfer in a Mediterranean grazing-land ecosystem," Journal of Environmental Radioactivity, vol. 55, no. 3, pp. 283-302, 2001.

[32] S. Gaglioti, E. Infusino, T. Caloiero, G. Callegari, and I. Guagliardi, "Geochemical characterization of spring waters in the Crati River Basin, Calabria (Southern Italy)," Geofluids, vol. 2019, Article ID 3850148, 2019.

[33] ICRP, The 2007 Recommendations of the International Commission on Radiological Protection, ICRP Publication 103, Pergamon Press, New York, 2007.

[34] J. L. Alvarez, Ionizing Radiation Risk Assessment, V. Molak, Ed., Fundamental of Risk Analysis and Risk Management, CRC Press, New York, 1997.

[35] ICRP, Recommendations of the International Commission on Radiological Commission, ICRP Publication 60, Pergamon Press, New York, 1990.

[36] I. Velde and A. Meunier, The Origin of Clay Minerals in Soils and Weathered Rocks, Springer-Verlag, Berlin, 2008.

[37] Electric Power Research Institute, Program on Technology Innovation: Evaluation of Updated Research on the Health Effects and Risks Associated with LD Ionizing Radiation, Electric Power Research Institute, Palo Alto, CA, 2009.

[38] American Association of Physicists in Medicine, AAPM Position Statement on Radiation Risks from Medical Imaging Procedures, 2011, http://www.aapm.org/org/policies/details .asp? $\mathrm{id}=318$ \& type $=\mathrm{PP}$.

[39] E. Cardis, M. Vrijheid, and M. Blettner, "The 15-country collaborative study of cancer risk among radiation workers in the nuclear industry: estimates of radiation-related cancer risks," Radiation Research, vol. 167, no. 4, pp. 396-416, 2007.

[40] M. Vrijheid, E. Cardis, and M. Blettner, "The 15-country collaborative study of cancer risk among radiation workers in the nuclear industry: design, epidemiological methods and descriptive results," Radiation Research, vol. 167, no. 4, pp. 361-379, 2007.

[41] D. B. Richardson, E. Cardis, R. D. Daniels et al., "Risk of cancer from occupational exposure to ionising radiation: retrospective cohort study of workers in France, the United Kingdom, and the United States (INWORKS)," British Medical Journal, vol. 351, 2015.

[42] K. Leuraud, D. B. Richardson, E. Cardis et al., "Ionising radiation and risk of death from leukaemia and lymphoma in radiation-monitored workers (INWORKS): an international cohort study," Lancet Haematology, vol. 2, pp. 276281, 2015.

[43] A. Vaiserman, A. Koliada, O. Zabuga, and Y. Socol, "Health impacts of low-dose ionizing radiation: current scientific debates and regulatory issues," Dose Response, vol. 16, 2018. 